\title{
EKSPRESI HONORIFIK, DAN STATUS SOSIAL DALAM MASYARAKAT JAWA
}

\section{LANGUAGE, HONORIFICS EXPRESSIONS, AND SOCIAL STATUS IN JAVANESE SOCIETY}

\author{
Dwi Atmawati \\ Balai Bahasa Daerah Istimewa Yogyakarta \\ dwi_bbs@yahoo.co.id
}

\begin{abstract}
ABSTRAK
Beragamnya ekspresi honorifik dalam masyarakat Jawa telah menimbulkan ketertarikan bagi penulis untuk mengkajinya. Ekspresi honorifik yang dipaparkan ini mencakup gelar bangsawan dan kata sapaan di Daerah Istimewa Yogyakarta (DIY). Penelitian ini menggunakan metode padan untuk mengkaji satuan lingual tertentu dengan menggunakan alat penentu luar bahasa. Berdasarkan data dan analisis yang dilakukan diketahui bahwa gelar pada kaum bangsawan antara lain rara, gusti raden ajeng, gusti raden ayu, kanjeng pangeran harya, gusti bendara raden mas, gusti bendara raden ajeng, gusti bendara raden ayu, bendara raden mas, bendara kanjeng pangeran, bendara raden ajeng, bendara raden ayu. Kata sapaan berdasarkan kelas sosial, diklasifikasi menjadi tiga: kelas atas, menengah, dan bawah. Kata sapaan pada masyarakat kelas atas antara lain papi, mami, papa/papah, mama/mamah, daddy, mom, tante, om, oma, opa, eyang, jeng. Kata sapaan pada masyarakat kelas menengah antara lain ayah, ibu, bapak, bunda, abi, ummi, paman, bibi, mas, mbak. Kata sapaan pada masyarakat kelas bawah antara lain pak/bapak, mbok/embok/simbok 'ibu', biyung 'ibu', mbakyu 'kakak/saudara tua perempuan', pakdhe 'kakak laki-laki ayah/ibu', mbokdhe kakak perempuan ayah/ibu', paklik 'om', bulik 'tante'. Kata sapaan yang mengalami penurunan jumlah penggunanya ialah embok/mbok/simbok dan biyung. Pemilihan kata sapaan erat hubungannya dengan status sosial penggunanya.
\end{abstract}

Kata kunci: bahasa, bangsawan, ekspresi honorifik

\begin{abstract}
Various titles and honorifics expressions in Javanese society has become particular interest for writer to analyze. The honorific expressions described in this paper include the title of nobility and greeting word in Daerah Istimewa Yogyakarta. The research uses equality method to review particular lingual unit using determiner tools beyond language. Based on the data and analysis it is known that titles of the nobles are rara, gusti raden ajeng, gusti raden ayu, kanjeng pangeran harya, gusti bendara raden mas, gusti bendara raden ajeng,
\end{abstract}


gusti bendara raden ayu, bendara raden mas, bendara kanjeng pangeran, bendara raden ajeng, bendara raden ayu. Where greeting word based on social class, the writer classifies it into three, upper, middle, and lower class. The greeting word on upper class society are such as papi, mami, papa/papah, mama/mamah, daddy, mom, tante, om, oma, opa, eyang, jeng. The greeting word on middle class society are such as ayah, ibu, bapak, bunda, abi, ummi, paman, bibi, mas, mbak. The greeting word on lower class society are such as pak/bapak, mbok/embok/simbok, biyung, mbakyu, pakdhe, mbokdhe, paklik, bulik. The greeting word are decreasing in number are embok/mbok/simbok dan biyung. Defining the greeting word is tightly associated to social status of the speakers.

Keywords: language, nobleman, honorifics expressions

\section{PENDAHULUAN}

Sebelum menjadi negara republik, Indonesia merupakan negara yang memiliki banyak kerajaan. Beberapa kerajaaan tersebut antara lain Kerajaan Kaling, Kerajaan Demak, Kerajaan Mataram Hindu di Jawa Tengah; Kerajaan Mataram Islam di Yogyakarta; Kerajaan Majapahit, Kerajaan Singasari di Jawa Timur; Kerajaan Tarumanegara di Jawa Barat; Kerajaan Makassar di Sulawesi Selatan; Kerajaan Kutai di Kalimantan Timur; Kerajaan Banjar di Kalimatan Selatan; Kerajaan Sriwijaya di Sumatra, Kerajaan Bali di Bali, Kerajaan Samodra Pasai di Aceh.

Kerajaan-kerajaan tersebut telah meninggalkan jejak sejarah bagi bangsa Indonesia, baik peninggalan yang berupa benda-benda maupun hal-hal yang berhubungan dengan kebahasaan, misalnya istilah-istilah/kosakata tertentu yang digunakan di lingkungan kerajaan. Kosakata tertentu yang masih digunakan sampai saat ini misalnya gelar kebangsawanan. Dalam masyarakat Jawa gelar kebangsawanan tersebut masih digunakan, utamanya dalam lingkungan keraton atau orang di luar lingkungan keraton yang diberi gelar oleh pihak keraton. Beragamnya gelar dan kata sapaan dalam masyarakat Jawa ini telah menimbulkan ketertarikan bagi penulis untuk mengkajinya. Tujuan kajian ini ialah mendeskripsikan dan menjelaskan hubungan antara ekspresi honorifik tentang gelar kebangsawanan, kata sapaan, dan status sosialnya pada masyarakat Jawa.

Adapun penelitian terdahulu yang terkait dengan kajian ini antara lain berjudul "Penggunaan Kata Sapaan pada Masyarakat Jawa di Desa Jombang, Kecamatan Jombang, Kabupaten Jember" karya Saadah, Asrumi, dan Ali Badrudin (2016). Hasil penelitian tersebut menunjukkan bahwa kata sapaan banyak mengalami perubahan. Pada keluarga usia muda penggunaan kata sapaan cenderung berubah. Hal itu disebabkan oleh keluarga usia muda lebih mudah untuk menerima perkembangan zaman (Saadah, Asrumi, dan Ali Badrudin, 2016:6). Penelitian berikutnya berjudul “Analisis Ungkapan Honorifik Mutlak 
dalam Mengakomodasi Sapaan dan Verba Keislaman pada Novel Karya Okky Madasari" karya Zaman, Nababan, dan Djatmika (2018). Dari hasil kajian tersebut diketahui bahwa sapaan keagamaan kebangsawanan, masyarakat umum dan verba keislaman mampu berintegrasi pada novel karya Okky Madasari (Zaman, Nababan, dan Djatmika, 2018:125).

Perbedaan kajian ini dengan penelitian tersebut ialah adanya perluasan kajian, yakni tentang penggunaan gelar kebangsawanan dan penggolongan kata sapaan berdasarkan kelas sosial pada masyarakat Jawa, khususnya di DIY. Hasil kajian ini diharapkan bermanfaat untuk memperkaya bidang sosiolinguistik dan mengetahui hubungan antara gelar kebangsawanan, kata sapaan, dan status sosialnya dalam masyarakat Jawa.

\section{METODE}

Penelitian ini merupakan penelitian deskriptif kualitatif dengan sasaran kasus penggunaan gelar kebangsawanan dan kata sapaan dalam masyarakat Jawa di wilayah DIY. Data penelitian ini ialah gelar kebangsawanan yang penulis peroleh dari internet dan kata sapaan dalam masyarakat Jawa di wilayah Yogyakarta. Data bersumber dari tuturan lisan sehari-hari dan studi pustaka pada internet. Instrumen penelitian ini ialah penulis sendiri yang memahami teori penggunaan bahasa dalam masyarakat. Pengumpulan data dilakukan dengan teknik yang simak, rekam, dan catat. Penulis menyimak, merekam, dan mencatat percakapan yang dilakukan. Setelah terkumpul, data diklasifikasi berdasarkan penggunaan gelar pada kaum bangsawan dan kata sapaan berdasarkan kelas sosial dalam masyarakat Jawa, yang terdiri atas masyarakat kelas atas, kelas menengah, dan kelas bawah. Klasifikasi tersebut mengacu pada teori Koentjaraningrat (1980) yang penulis sederhanakan. Setelah diklasifikasi, data dianalisis dan dijelaskan penggunaannya. Analisis dilakukan dengan metode padan dan analisis fungsional dan kontekstual. Metode padan digunakan untuk mengkaji satuan lingual tertentu dengan menggunakan alat penentu luar bahasa. Analisis fungsional dan kontekstual dilakukan dengan menghubungkan antara bentuk-bentuk kebahasaan dan ciri sosio-situasional-kultural. Analisis ini mengacu pada teori sosiolinguistik tentang bahasa dan masyarakat.

\section{PEMBAHASAN}

Indonesia yang pada masa lalu sebelum menjadi republik terdiri atas kerajaan-kerajaan telah meninggalkan jejak sejarah, baik peninggalan yang berupa situs-situs purbakala maupun peninggalan yang terkait dengan penggunaan bahasa. Adanya raja dan rakyat tentu telah memunculkan kelas sosial yang berpengaruh pada pilihan bentuk-bentuk bahasa yang digunakan, termasuk dalam masyarakat suku Jawa. Suku Jawa memiliki bahasa daerah yang disebut bahasa 
Jawa. Bahasa Jawa merupakan sebagian cermin dan budaya masyarakat Jawa. Dalam kaitannya dengan gelar dan sapaan pun, orang Jawa memiliki keragaman. Untuk itu, dalam penelitian ini dibahas penggunaan bahasa, gelar, sapaan yang disematkan pada orang Jawa dalam hubungannya dengan status sosial dalam masyarakatnya.

Sebelum membahas lebih lanjut, perlu penulis kemukakan definisi bangsawan. Sebutan bangsawan merujuk pada orang yang masih keturunan raja, termasuk kerabatnya. Bangsawan sering digunakan untuk menyebut orang yang berdarah biru atau ningrat. Kata bangsawan 'aristocratic' berantonim dengan proletar. Istilah kaum bangsawan disebut nobility (bahasa Inggris), noblesse (bahasa Prancis), adel (bahasa Jerman), la nobiltà (bahasa Italia), la nobleza (bahasa Spanyol). Dikenalnya istilah bangsawan dalam beberapa bahasa asing tersebut menunjukkan bahwa di negara-negara itu ada kaum bangsawan. Adanya istilah yang mengacu pada referen yang sama dalam berbagai bahasa menunjukkan bahwa bahasa bersifat universal.

Koentjaraningrat mengelompokkan masyarakat Jawa dalam empat tingkat, yaitu wong cilik, saudagar, priyayi, dan ndara (1980:245). Bahasa yang digunakan oleh wong cilik berbeda dengan bahasa yang digunakan oleh saudagar, priyayi, atau ndara. Penutur memilih variasi bahasa biasanya sesuai dengan tingkat sosialnya. Pemilihan variasi bahasa itu berkaitan dengan faktor sosiologis yang hendak dicapai. Faktor penyebab perbedaan variasi bahasa antara lain usia, keturunan, perkawinan, jenis kelamin. Orang menggunakan kata santap daripada kata makan pada situasi dan lingkungan tertentu. Kata bersantap 'makan' pada frasa bersantap siang 'makan siang' hanya ditujukan pada orang tertentu, misalnya orang yang masih keturunan ningrat atau dalam lingkungan keraton atau orang yang dihormati.

Sesuai dengan judul tulisan ini, berikut penulis sajikan pembahasan penggunaan varian bahasa dalam kata sapaan dan gelar kebangsawanan orang Jawa. Untuk menjawab permasalahan dalam kajian ini, penulis mengklasifikasi data berdasarkan perbedaan kelas yang dikemukakan oleh Maliki (2010), yakni kelas atas, menengah, dan bawah (Triwijayati dan Pradipta, 2018:143-144). Mengenai kelas sosial, Shadily menyatakan bahwa kelas sosial adalah golongan yang terbentuk karena perbedaan kedudukan tinggi dan rendah, serta adanya perasaan segolongan dalam kelas tersebut (Shadily dalam Abdulsyani, 2012:89). Kelas sosial adalah hierarki kelas yang anggota setiap kelasnya relatif memiliki status sama dan anggota kelas lainnya memiliki status lebih tinggi atau lebih rendah (Furaiji, 2012). 


\section{Hubungan antara Bahasa dan Tingkatan Sosial dalam Masyarakat Jawa}

Pada kesempatan ini penulis sajikan hubungan antara bahasa dan tingkat sosial di dalam masyarakat ditinjau dari penggunaan kata sapan dan gelar yang disematkan. Penggunaan kata sapaan dan gelar kebangsawanan ini merupakan contoh bentuk ekspresi honorifik. Dalam Kamus Besar Bahasa Indonesia (2016). dinyatakan bahwa honorifik ialah "berkenaan dengan penggunaan ungkapan penghormatan dalam bahasa untuk menyapa orang tertentu". Pengguna kata sapaan biyung, embok, simbok dalam masyarakat Jawa tampaknya mulai berkurang jumlahnya. Mereka beralih dengan memilih kata sapaan ibu. Hal tersebut terjadi karena pesatnya pengaruh teknologi yang dapat dengan mudah tersebar hingga ke pelosok-pelosok.

Data diklasifikasi berdasarkan penggunaan gelar pada kaum bangsawan dan kata sapaan dalam masyarakat yang disebabkan oleh perbedaan kelas atau tingkat sosial. Kelas sosial ini dipilah berdasarkan tingkat pendidikan dan tingkat perekonomian. Pada kelas sosial ini data diklasifikasi berdasarkan pengguna kata sapaan, yakni masyarakat kelas sosial tinggi, menengah, dan rendah. Masyarakat dengan status sosial tinggi ditandai antara lain harta yang berlimpah/kaya, keturunan bangsawan, memiliki kedudukan di masyarakat, kadang-kadang tingkat pendidikan cukup tinggi. Masyarakat dengan status sosial menengah ditandai antara lain hidup berkecukupan, memiliki pekerjaan tetap, pendidikan cukup tinggi. Masyarakat dengan status sosial rendah biasanya ditandai dengan penghasilan yang tidak mencukupi untuk memenuhi kebutuhan hidup sehari-hari.

\section{Penggunaan gelar pada kaum bangsawan}

Sebelum membahas penggunaan gelar dan kata sapaan lebih lanjut, perlu penulis kemukakan yang dimaksud kata sapaan. Kata sapaan adalah kata yang digunakan untuk menyapa orang yang diajak berbicara atau menggantikan nama orang ketiga (http://badanbahasa.kemdikbud.go.id/lamanbahasa/petunjuk_praktis/495/Kat\%20 Sapaan\%20\%20Dalam\%20Bahasa). Penggunaan gelar atau kata sapaan pada masyarakat kelas atas ini ada yang disebabkan oleh faktor keturunan, misalnya gelar yang digunakan di lingkungan keraton. Gelar yang disebabkan oleh faktor keturunan misalnya rara (Rr.), gusti raden ajeng (G.R.A.), gusti raden ayu (G.R.Ay.), kanjeng pangeran harya (K.P.H.), gusti bendara raden mas (G.B.R.M.), gusti bendara raden ajeng (G.B.R.A.), gusti bendara raden ayu (G.B.R.Ay.), bendara raden mas (B.R.M.), bendara kanjeng pangeran (B.K.P.), bendara raden ajeng (B.R.A.), bendara raden ayu (B.R.Ay.).

Gelar rara (Rr.) merupakan gelar yang dapat diturunkan kepada anak cucunya tanpa batas asalkan keturunan pihak wanita memiliki kedudukan bangsawan yang tinggi. Gelar gusti raden ajeng (G.R.A.) merupakan gelar yang 
diberikan kepada anak perempuan dari permaisuri ketika belum menikah. Gelar gusti raden ayu (G.R.Ay.) merupakan gelar yang diberikan kepada anak perempuan dari permaisuri ketika sudah menikah. Gelar kanjeng pangeran harya (K.P.H.) diberikan kepada anak lelaki selain putra mahkota dari permaisuri ketika sudah dewasa. Gelar gusti bendara raden mas (G.B.R.M.) diberikan kepada anak lelaki selain putra mahkota dari permaisuri ketika masih muda. Gelar gusti bendara raden ajeng (G.B.R.A.) diberikan kepada anak perempuan dari permaisuri ketika belum menikah. Gelar gusti bendara raden ayu (G.B.R.Ay.) diberikan kepada anak perempuan dari permaisuri ketika sudah menikah. Gelar bendara raden mas (B.R.M.) diberikan kepada anak laki-laki dari selir ketika masih muda. Gelar bendara kanjeng pangeran (B.K.P.) diberikan kepada anak lelaki dari selir ketika sudah dewasa. Gelar bendara raden ajeng (B.R.A.) diberikan kepada anak perempuan dari selir ketika belum menikah. Gelar bendara raden ayu (B.R.Ay.) diberikan kepada anak perempuan dari selir ketika sudah menikah. Selain gelar kebangsawanan, terdapat juga sebutan khusus di lingkungan keraton, misalnya sekarkedhaton, sekartaji, dan candrakirana. Sebutan sekarkedhaton digunakan untuk menyebut putri sulung permaisuri raja. Sekartaji digunakan untuk menyebut putri kedua. Candrakirana digunakan untuk menyebut putri ketiga (https://id.wikipedia.org/wiki/Gelar_kebangsawanan_Jawa).

\section{Kata Sapaan Berdasarkan Kelas Sosial dalam Masyarakat Jawa}

Di kota besar yang masyarakatnya heterogen, tingkat status sosial berdasarkan derajat kebangsawanan sudah tidak begitu terlihat. Yang terlihat ialah tingkat kelas sosial masyarakat berdasarkan status sosial ekonominya. Berikut ini disajikan kata sapaan dalam masyarakat Jawa di DIY berdasarkan kelas sosialnya. Klasifikasi kelas sosial ini mengacu pada klasifikasi kelas sosial menurut Koentjaraningrat (1980) dengan penyederhanaan oleh penulis.

a. Kelas atas

Yang termasuk kelas atas ialah orang yang masih keturunan raja atau bangsawan, memiliki kekayaan di atas rata-rata, berpengaruh dalam masyarakat, berpenghasilan tinggi, berpendidikan tinggi minimal sarjana, berpola hidup modern, tinggal di kota. Beberapa gelar kebangsawanan yang sering difungsikan sebagai sapaan sudah penulis sajikan di atas. Oleh karena itu, di bagian ini penulis hanya menyajikan penggunaan sapaan pada kelas atas dari kelompok masyarakat yang bukan dari golongan kaum bangsawan atau ningrat.

Kata sapaan pada masyarakat kelas atas ini ada beberapa macam, misalnya papi, mami, papa/papah, mama/mamah, daddy, mom, tante, om, oma, opa, eyang, jeng. Kata papi 'ayah' merupakan kata sapaan anak kepada ayahnya atau istri kepada suaminya. Kata mami 'ibu' merupakan kata sapaan anak kepada ibunya atau suami kepada istrinya. Kata sapaan papi dan mami ini biasanya hanya 
digunakan oleh sebagian orang yang tinggal di perkotaan dari masyarakat kelas atas. Kata papa/papah 'ayah' merupakan kata sapaan kepada ayahnya atau istri kepada suaminya. Kata mama/mamah 'ibu' merupakan kata sapaan anak kepada ibunya atau suami kepada istrinya. Kata sapaan papah, mamah hanya merupakan varian dari kata sapaan papa dan mama. Fonem [ $h]$ pada kata papah dan mamah terpengaruh dari bahasa Sunda. Isnaeni mengemukakan bahwa dalam bahasa Sunda, orang sering menambahkan fonem $[h]$ pada akhir kata yang berakhir dengan vokal terbuka, misalnya kata rapi menjadi rapih, mama menjadi mamah (Isnaeni, https://historia.id/politik/articles/sejarah-panggilan-papah-dan-mamahDbxdP). Pemilihan kata sapaan papi, mami, papa/papah, mama/mamah dapat disebabkan oleh faktor pengucapan yang terdengar indah atau nilai gengsi yang dianggap lebih tinggi.

Menurut Majalah Pembinaan Bahasa Indonesia (1984), kata sapaan papi, mami, papa, dan mama berasal dari bahasa Belanda, yakni mammie dan pappie, mamma dan pappa, atau mammaatje dan pappaatje. Pada zaman kolonial kata sapaan tersebut digunakan untuk membedakan orang yang berpendidikan Belanda dengan yang tidak (https://historia.id/politik/articles/sejarah-panggilan-papah-danmamah-DbxdP).

Selanjutnya, kata daddy 'ayah' dan mom 'ibu' merupakan kata sapaan dalam bahasa Inggris. Kata daddy kadang-kadang digunakan juga oleh sebagian anak untuk menyebut ayahnya dan kata mom digunakan juga oleh sebagian anak untuk menyebut ibunya. Ada anggapan bahwa penggunaan kata sapaan daddy dan mom dianggap prestisius. Kemudian, kata tante menurut Kamus Besar Bahasa Indonesia (2016) berarti adik atau kakak perempuan ayah atau ibu atau kata sapaan kepada wanita yang agak tua. Sukatno mengemukakan bahwa kata sapaan om, tante diserap dari bahasa Belanda oom, tante (https://id.quora.com/Darimana-asal-kata-om-dan-tante). Pilihan kata sapaan om dan tante ini digunakan oleh masyarakat kelas atas dan sebagian masyarakat modern. Kata sapaan opa 'kakek' dan oma 'nenek' digunakan dalam masyarakat modern dan kalangan atas. Adapun kata sapaan eyang 'kakek/nenek' biasanya digunakan oleh orang Jawa yang masih kental budaya Jawanya. Berikutnya ialah kata sapaan jeng. Kata sapaan jeng biasanya digunakan untuk menyebut perempuan muda atau paruh baya di kalangan kelas atas.

b. Kelas menengah

Yang termasuk dalam kelas menengah ialah orang yang berpendidikan tinggi dan bisa memenuhi kebutuhannya sehari-hari serta memiliki kemampuan ekonomi untuk mempersiapkan kebutuhan hidupnya pada masa depan, misalnya kebutuhan pendidikan anak-anaknya. Kata sapaan yang digunakan dalam masyarakat kelas menengah antara lain ayah, ibu, bapak, bunda, abi, ummi, paman, bibi, mas, mbak. 
Kata sapaan ayah, ibu, kakek, nenek ini banyak digunakan oleh masyarakat kelas menengah yang menggunakan bahasa Indonesia sebagai bahasa sehariharinya. Namun demikian, kata sapaan $i b u$ juga sering digunakan oleh orang yang berbahasa ibu bahasa Jawa. Begitu juga, kata sapaan bapak sering digunakan oleh anak untuk menyebut ayahnya, baik yang berbahasa Jawa maupun berbahasa Indonesia dalam berkomunikasi sehari-hari. Selain itu, kata sapaan bapak sering juga digunakan oleh istri untuk menyebut suaminya dan kata sapaan ibu sering juga digunakan oleh suami untuk menyebut istrinya. Penyebutan tersebut tujuannya untuk mengajarkan kepada anak-anaknya dalam menyebut orang tuanya. Kata sapaan bunda tampaknya semakin banyak digunakan untuk menyebut $i b u$, baik sebagai kata sapaan oleh seorang anak kepada ibunya maupun sapaan kepada wanita yang sudah menikah.

Berikutnya ialah kata sapaan ummi dan abi. Kata sapaan ummi dan abi berasal dari bahasa Arab. Kata sapaan ummi 'ibu' dan abi 'ayah' biasanya digunakan di kalangan orang-orang agamais yang beragama Islam. Kata sapaan ummi dan abi ini semakin banyak digunakan seiring dengan makin berkembangnya dakwah Islam. Kata sapaan paman dan bibi biasa digunakan oleh masyarakat menengah. Menurut KBBI (2016) kata sapaan paman digunakan untuk mengacu adik laki-laki ayah atau ibu, Kata sapaan bibi digunakan untuk mengacu adik (saudara muda) perempuan dari ayah atau ibu. Selain itu, kata sapaan bibi digunakan untuk menyebut pembantu rumah tangga yang berjenis kelamin perempuan. Kata sapaan mas digunakan untuk menyebut kakak laki-laki atau orang laki-laki yang usianya di atas orang yang mengajak berbicara atau orang laki-laki yang berusia lebih muda, tapi belum penutur belum mengenalnya. Kata sapaan mbak digunakan untuk menyebut kakak perempuan atau orang perempuan yang usianya di atas orang yang mengajak berbicara atau orang lakilaki yang berusia lebih muda, tapi belum penutur belum mengenalnya. Kata sapaan mbak dan mas kadang-kadang juga digunakan dalam kalangan kelas atas.

c. Kelas bawah

Yang termasuk kelas bawah ialah orang yang bekerja sebagai buruh kasar, berpenghasilan rendah, atau tidak memiliki pekerjaan. Golongan kelas bawah ini bekerja untuk memenuhi kebutuhan hidup sehari-hari. Kadang-kadang kebutuhannya tidak terpenuhi meskipun orang tersebut sudah bekerja keras. Di kalangan kelas bawah ini ada beberpa kata sapaan yang biasa digunakan. Kata sapaan yang digunakan antara lain pak/bapak, mbok/embok/simbok, biyung, mbakyu, pakdhe, mbokdhe, paklik, bulik. Kata sapaan pak merupakan bentuk pendek dari kata bapak. Kata sapaan pak ini digunakan oleh anak untuk menyebut ayahnya atau istri untuk menyebut suaminya atau orang laki-laki dewasa. Kata sapaan mbok merupakan bentuk pendek dari embok. Kata sapaan mbok/embok/simbok 'ibu' ini biasanya hanya digunakan di pelosok pedesaan. Di 
pelosok pedesaan dengan taraf ekonomi yang rendah, biasanya seorang anak memanggil ibunya dengan kata sapaan mbok/embok/simbok. Selain itu, kata mbok/embok/simbok juga digunakan untuk menyapa pembantu tumah tangga. Kata sapaan biyung 'ibu' juga hanya dapat dijumpai di pelosok pedesaan. Akan tetapi, kata biyung tampaknya mulai jarang digunakan atau sedikit penggunanya.

Berikutnya ialah kata sapaan mbakyu 'kakak perempuan'. Di kalangan menengah ke atas, orang menyebut kakak perempuan dengan kata sapaan mbak, tetapi di kalangan kelas rendah orang menyebut kakak permpuan dengan kata sapaan mbakyu. Namun, kadang-kadang di kalangan atas kata sapaan mbakyu juga digunakan. Kata sapaan mbakyu merupakan pendek dari mbak ayu. Kata sapaan pakdhe merupakan bentuk pendek dari bapak gedhe. Kata sapaan pakdhe mengacu pada kakak laki-laki dari ibu atau ayah. Kata sapaan pakdhe ini digunakan, baik di kalangan bawah, menengah maupun atas. Kata sapaan mbokdhe merupakan bentuk pendek dari embok gedhe. Kata sapaan mbokdhe mengacu pada kakak perempuan dari ibu atau ayah. Kata sapaan mbokdhe biasanya hanya digunakan di kalangan bawah atau rendah, sedangkan di kalangan menengah dan atas biasanya digunakan kata sapaan budhe.

Kata sapaan paklik dan bulik merupakan bentuk pendek dari bapak cilik dan ibu cilik. Kata sapaan pak lik mengacu pada adik laki-laki dari ibu atau ayah. Kata sapaan bulik mengacu pada adik perempuan dari ibu atau ayah. Di kalangan masyarakat bawah, kata sapaan paklik ini kadang-kadang bentuknya dipendekkan lagi menjadi lik saja. Begitu juga, kata sapaan bulik dipendekkan menjadi lik saja.

\section{PENUTUP}

Dalam masyarakat Jawa yang memiliki bahasa-ibu bahasa Jawa dikenal beberapa gelar kebangsawanan dan kata sapaan. Gelar kebangsawanan dan kata sapaan tersebut terkait dengan budaya yang hidup pada masa lalu dan diwariskan secara turun temurun. Kata sapaan dalam masyarakat Jawa terbagi dalam kelaskelas yang berbeda penggunaannya. Dalam kajian ini penulis memilah penggunaan gelar kata sapaan menjadi dua, yakni penggunaan gelar pada kaum bangsawan dan kata sapaan berdasarkan kelas sosial dalam masyarakat Jawa.

Adapun kata sapaan berdasarkan kelas sosial, penulis klasifikasi menjadi tiga, yakni kelas atas, menengah, dan bawah. Kata sapaan yang mengalami penurunan jumlah penggunanya ialah embok/mbok/simbok dan biyung. Penurunan jumlah itu antara lain disebabkan oleh mudahnya teknologi informasi menyebar sampai ke pelosok nusantara. Perkembangan teknologi informasi tersebut dapat memengaruhi banyak hal. Salah satunya ialah penggunaan kosakata di suatu wilayah dengan mudah tersebar ke wilayah lain dan ditiru oleh orang lain. Namun demikian, pemilihan kata sapaan tampaknya tidak dapat begitu saja terlepas dari 
status sosial penggunanya. Terdapat hubungan yang erat antara bahasa, kata sapaan, gelar kebangsawanan, dan status sosial dalam masyarakat Jawa.

\section{DAFTAR PUSTAKA}

Furaiji, F., Latuszynska, M., \& Wawrzyniak, A. (2012). An Empirical Study of the Factors Influencing Consumer Behavior in the Electric Appliances Market. Journal of Contemporary Economic, 6(3), 76-86. doi: 10.5709/ce.1897-9254.52.

https://papers.ssrn.com/sol3/papers.cfm?abstract_id=2179897

http://badanbahasa.kemdikbud.go.id/lamanbahasa/petunjuk_praktis/495/Kat\%20S apaan\%20\%20Dalam\%20Bahasa. Diakses pada 19 Februari 2020.

https://id.wikipedia.org/wiki/Gelar_kebangsawanan_Jawa.

Isnaeni, Hendri F. Sejarah Panggilan Papah dan Mamah. https://historia.id/politik/articles/sejarah-panggilan-papah-dan-mamahDbxdP. Diakses pada 4 November 2019.

Kamus Besar Bahasa Indonesia. (2016). https://kbbi.kemdikbud.go.id/entri/tante. Diakses pada 4 November 2019.

Koentjaraningrat. (1980). Pengantar Antropologi. Jakarta: Aksara Baru.

Majalah Pembinaan Bahasa Indonesia. 1984. 5-8. dalam https://historia.id/politik/articles/sejarah-panggilan-papah-dan-mamahDbxdP. Diakses pada 4 November 2019.

Maliki, Zainuddin. (2010). Sosiologi Politik: Makna Kekuasaan dan Transformasi Politik. Yogyakarta: Gadjah Mada University Press.

Saadah, Imarotus, Asrumi, dan Ali Badrudin. (2016). Penggunaan Kata Sapaan pada Masyarakat Jawa di Desa Jombang, Kecamatan Jombang, Kabupaten Jember. Publika Budaya, 1(1), 1-7. http://repository.unej.ac.id/bitstream/handle/123456789/79231/IMAROTUS $\%$ 20SAADAH.pdf?sequence $=1$

Shadily dalam Abdulsyani (2012). Sosiologi Skematika, Teori, dan Terapan. Jakarta: PT Bumi Aksara.

Triwijayati, Anna dan Deviga Bayu Pradipta. (2018). Kelas Sosial vs Pendapatan: Eksplorasi Faktor Penentu Pembelian Consumer Goods dan Jasa. Jurnal Ekonomi, 23(2), 141-158. doi: http://dx.doi.org/10.24912/je.v23i2.365.

Zaman, Mochamad Nuruz, Mangatur Rudolf Nababan, dan Djatmika. (2018). Analisis Ungkapan Honorifik Mutlak dalam Mengakomodasi Sapaan dan Verba Keislaman pada Novel Karya Okky Madasari. Khazanah: Jurnal Studi Islam dan Humaniora, 18(1), 125-142. doi: http://dx.doi.org/10.18592/khazanah.v16i1.2130 